
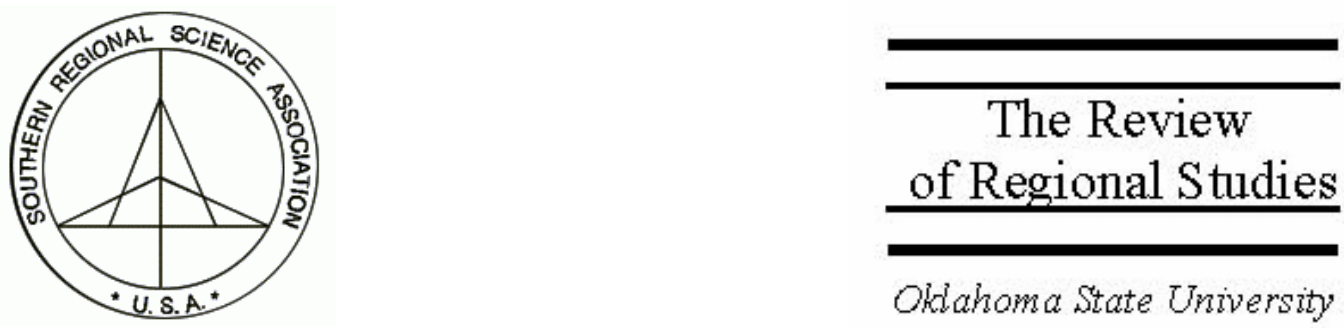

\title{
Education and Economic Well-Being in Racially Diverse Rural Counties: The Role of Historically Black Colleges and Universities
}

\author{
Elton Mykerezi \\ Department of Agricultural and Applied Economics, Virginia Polytechnic Institute \\ and State University, 314 Hutcheson Hall, Blacksburg, VA 24060, \\ e-mail: Elmykere@vt.edu \\ Bradford F. Mills \\ Department of Agricultural and Applied Economics, Virginia Polytechnic Institute \\ and State University, 314 Hutcheson Hall, Blacksburg, VA 24060, \\ e-mail:Bfmills@vt.edu
}

\begin{abstract}
The role of Historically Black Colleges and Universities (HBCUs) in increasing the education and economic well-being of rural Blacks is not, perhaps, as clear today as in the past given the abolition of formal segregation in public education. This paper presents evidence that HBCUs still play a major role in improving the economic well being of rural counties with high concentrations of Blacks. Further, the impact of HBCUs in promoting college education among Blacks is above and beyond that of other colleges and universities. Increased rates of college education generate, in turn, higher income growth.
\end{abstract}

Keywords: Historically Black Colleges and Universities; Blacks; Rural south; Income

JEL classification: R12; I21; R53

This research project was funded by the National Research Initiative Award (USDA/CSREES Grant number 2003-35401-12915). 


\section{INTRODUCTION}

Historically Black Colleges and Universities (HBCUs) have played a crucial role in the education of Black Americans. Throughout most of their history, during times of de jure and de facto segregation in postsecondary education, HBCUs were virtually the only sources of higher education accessible to southern Blacks. The role of HBCUs has changed since the end of formal segregation in public postsecondary education 50 years ago under the Supreme Court ruling in the case of Brown v. The Board of Education of Topeka (1954).

Several recent studies, however, document the major role that HBCUs continue to play in the postsecondary education of Blacks. In 1995, HBCUs hosted 26 percent of all Black students enrolled in four-year colleges, awarded masters degrees and first professional degrees to about 1 in 6 Black men and women, and awarded 27 percent of all baccalaureate degrees earned by Blacks nationwide (U.S. Department of Education 1997). HBCUs also continue to play a particularly important role in increasing the earnings and achievement of Black Americans. For example, the earnings of Blacks are estimated to be 38 percent higher with a college degree from a Historically Black College or University than with a college degree from other institutions (Constantine 1995). A disproportionate number of Black Ph.D. holders also list a Historically Black College or University as their school of undergraduate studies (Brazziel 1983).

Few studies have focused on the contributions of HBCUs to nearby communities in terms of postsecondary education and subsequent earnings. Mykerezi, Mills, and Gomes (2003) estimate that for U.S. rural counties in which at least one third of the population is Black, the incidence of college degrees among Black adults drops by 5.8 percentage points per 100 miles distance from the nearest HBCU. Similarly the 1990s' rate of growth in the share of the adult Black population with a college degree declines by 1.2 percentage points per 100 miles distance, even after controlling for the presence of other colleges and universities in the area.

A strong relationship between HBCUs and local community economic growth is an important reason for continued strong public support. The current paper builds on the work of Mykerezi, Mills, and Gomes (2003) by exploring the postsecondary education contributions of HBCUs to nearby racially diverse rural communities at the more refined level of county subdivisions. In addition, the current study explores the impact of postsecondary education on the economic well being of the communities that HBCUs most directly serve through their proximity. To pursue these objectives, the rest of the paper is organized as follows. Section 2 briefly outlines the mandates of HBCUs, their geographic concentration in the South, and the location of the racially diverse rural communities that are the focus of study. Section 3 reviews the data used in the analysis. Section 4 examines the influence that proximity to HBCUs has on the incidence of college degrees in racially diverse rural counties. Section 5 examines the impact that postsecondary education attainment has on income growth in racially diverse rural counties. Section 6 distills conclusions and policy implications. 


\section{HBCUS AND RACIALLY DIVERSE RURAL COUNTIES}

HBCUs were established to provide equal educational opportunities for students denied admission to their states' original 1862 land-grant university system. The Higher Education Act of 1965, as amended, defines an HBCU as: "any Historically Black College or University that was established prior to 1964, whose principal mission was, and is, the education of Black Americans, and that is accredited by a nationally recognized accrediting agency or association determined by the Secretary [of Education] to be a reliable authority as to the quality of training offered or is, according to such an agency or association, making reasonable progress toward accreditation." Currently there are 105 HBCUs that are nationally or regionally accredited; 18 of these institutions were established as 1890 Land Grants, and 51 are publicly funded.

A disproportionate number of HBCUs, including most publicly funded ones and all 181890 Land Grants are located in the South, many in predominantly rural areas (Figure 1). Their location is a logical reflection of the mandate to improve access to higher education for historically disadvantaged Blacks. The rural South has historically been the poorest geographic region in the nation, with persistent low levels of educational attainment and low incomes as well as a high incidence of poverty. Blacks are strongly concentrated in the rural South, with over 89 percent of all rural Blacks living in the region. In addition, Blacks show a high rate of poverty in the rural South (31.6 percent) when compared to the national average (23.0 percent).

\section{FIGURE 1}

\section{Location of RDRCs and HBCUs}

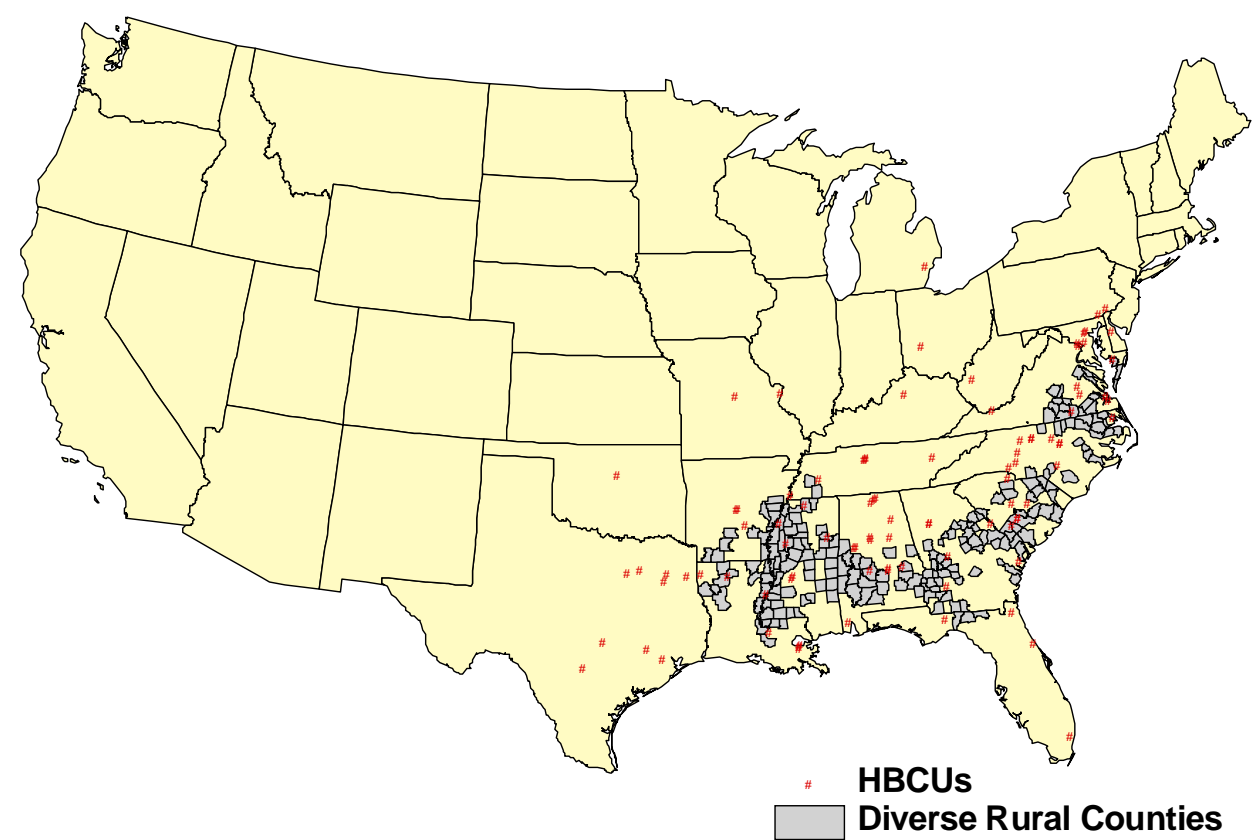


Several studies present evidence that an individual's geographic proximity to educational institutions is related to his or her educational attainment. For example, Card (1995) finds that closer residence to a college or university is positively correlated with educational attainment. Card (1995) also finds that proximity to colleges and universities has a larger impact on educational outcomes of individuals whose parents have low levels of education, suggesting that the location of colleges and universities in historically less well-off areas, where postsecondary education attainment tends to be lower, may have a greater impact on local educational attainment than location in relatively well-off areas. Proximity may be especially important for poor rural Blacks, who continue to face financial, social, and information barriers to college enrollment. Enrollment rates among rural Blacks may also be lower due to lower rates of return on their educational investment compared with Whites (Darity and Mason 1998).

\section{DATA}

This paper relies primarily on Census-designated county subdivision-level data from the 2000 and 1990 U.S. Census of Population and Housing. Counties and their subdivisions that are defined as non-metropolitan based on the 1990 U.S. Census of Population and Housing are designated as rural in the study. ${ }^{1}$ The base U.S. Bureau of Census data for 1990 contains 2,300 rural counties with 24,281 county subdivisions. The subdivision variables used in the analysis are actually generated from a complex underlying Census sample design (U.S. Census 1990). Two factors of the design are of note. First, Census sampling rates vary with the size of the government unit (county or county equivalent) and the Census tract being sampled. Many of the subdivisions of the racially diverse rural counties are located in small governmental units or Census tracts and are therefore over-sampled relative to larger units. This over-sampling reduces the variability of the estimated values of the variables from the actual 100 percent count. Second, to preserve confidentiality, individual observations are replaced with imputed responses for a small subset of the data. This subset is also proportionally larger in small areas to provide greater confidentiality. No adjustments in the estimates are made to explicitly account for these components of the sample design. All estimates, however, are weighted by subdivision population size, and the multivariate regressions are corrected for heteroskedasticity that might arise from the complex sample design.

The study also makes use of U.S. Census TIGER database county subdivision center coordinates and the Department of Education's Postsecondary Education Participation System college and university zip codes to generate straight line distance measures from each county subdivision to the nearest college or university, nearest public college or university, and nearest HBCU.

The Economic Research Service has defined racially diverse rural counties as those counties that in 1990 were classified as nonmetropolitan by the U.S. Census and that had

\footnotetext{
${ }^{1}$ The same counties are designated as rural for the year 2000 even though some of these counties were reclassified as metropolitan following analysis of the 2000 U.S. Census data.
} 
one third or more of the county population comprised by a major ethnic or racial minority. We will define racially diverse counties in a similar fashion, but applied only to Blacks. There are 208 U.S. counties that fit this definition, and they are exclusively located in the rural South (Figure 1). The 208 racially diverse rural counties contain 1,114 county subdivisions.

Table 1 presents county subdivision population-weighted summary statistics for the variables used in this study. In 2000, only 7.7 percent of Black adults 25 years of age or older had at least a four-year college degree in racially diverse rural counties, while 16.6 percent of Black adults in the U.S. and 25.9 percent of all U.S. adults had at least a college degree. The racially diverse rural counties also show significantly lower levels of per capita incomes and higher incidence of poverty than U.S. rural counties in general. Blacks within racially diverse rural counties show the lowest income levels; in 2000, their income was only 46 percent of the average U.S. per capita income and only 57 percent of the average rural population per capita income. Within racially diverse rural counties, however, the incomes of Blacks, while still lower $(\$ 9,741)$, are not very different from the incomes of the general population $(\$ 10,419)$.

\section{METHODOLOGY}

We specify and estimate linear regression models to determine whether greater access to HBCUs is associated with a higher share of the Black adult population with college degrees in 2000 and on the growth in this share between 1990 and 2000 in the subdivisions of racially diverse rural counties. Similar models are run for the general population to see if the impact of HBCUs is specific to Blacks in racially diverse rural counties.

Several empirical and modeling issues arise from this approach. The most important issues that are addressed below are: (1) measuring access to HBCUs, (2) identifying the marginal influence of HBCUs on educational attainment of Blacks, (3) addressing potential endogeneity of the location of HBCUs, and (4) addressing concerns about unequal populations in county subdivisions.

\subsection{Measuring Access}

The presence of HBCUs may improve the social, financial, and physical dimensions of access to postsecondary education among rural Blacks. The social distance associated with going to college, for instance, is less when the educational environment is shared among individuals with similar backgrounds (Akerlof and Kranton 2002). More frequent contact with HBCU alumni, students, and faculty in the community may also increase the perception that a college degree is a feasible and desirable goal. HBCUs may also make postsecondary education more affordable by providing a relatively low-cost college education. At the same time, HBCUs, by being predominantly located in the South, decrease the physical distance between home and college for rural Blacks, which in turn reduces social and financial costs. 
TABLE 1

List of Variables Used in the Empirical Model

\begin{tabular}{|c|c|c|c|c|c|}
\hline \multirow[b]{2}{*}{ Variable } & \multirow[b]{2}{*}{ Explanation } & \multicolumn{4}{|c|}{ Subdivisions of RDRCs Rural U.S. Subdivisions } \\
\hline & & Mean & Std. Dev. & Mean & Std. Dev. \\
\hline income00 & Per capita income in 2000 & 14,3920 & 95.2511 & 16,9670 & 24.3749 \\
\hline income90 & Per capita income in 1990 & 10,2901 & 117.5990 & 10,9191 & 54.4631 \\
\hline lnincome00 & Log of per capita income in 2000 & 9.5463 & 0.0065 & 9.7101 & 0.0009 \\
\hline Inincome90 & Log of per capita income in 1990 & 9.2100 & 0.0158 & 9.2622 & 0.0021 \\
\hline dlnincome & Change in the log of income $1999-2000$ & 0.3280 & 0.0150 & 0.4427 & 0.0036 \\
\hline educ00 & Fraction of adults with college degrees, 2000 & 0.1241 & 0.0019 & 0.1546 & 0.0002 \\
\hline educ90 & Fraction of adults with college degrees, 1990 & 0.1062 & 0.0016 & 0.1277 & 0.0005 \\
\hline deduc & Change in the fraction of adults with college degrees & 0.0161 & 0.0010 & 0.0242 & 0.0008 \\
\hline manu90 & Fraction of the employed population in manufacturing in 1990 & 0.3341 & 0.0032 & 0.2676 & 0.0006 \\
\hline serv90 & Fraction of the employed population in services in 1990 & 0.5904 & 0.0031 & 0.6411 & 0.0004 \\
\hline pblak & Blacks as a share subdivision population & & & 0.0825 & 0.0008 \\
\hline blckinc00 & Per capita income in 2000 (Black population) & 9,7410 & 65.9122 & 10,4190 & 25.6086 \\
\hline rbinc90 & Per capita income in 1990 (Black population) & 6,6990 & 52.1904 & 7,2981 & 28.5701 \\
\hline lnbinc00 & Log of per capita income in 2000 (Black population) & 9.1551 & 0.0067 & 9.2006 & 0.0024 \\
\hline lnbinc90 & Log of per capita income in 1990 (Black population) & 8.7740 & 0.0075 & 8.84911 & 0.0022 \\
\hline dlnbinc & Change in the log of income 1999-2000 (Black population) & 0.3776 & 0.0068 & 0.3513 & 0.0021 \\
\hline beduc00 & Fraction of adults with college degrees 2000 (Black population) & 0.0710 & 0.0008 & 0.0712 & 0.0007 \\
\hline beduc90 & Fraction of adults with college degrees 1990 (Black population) & 0.0590 & 0.0008 & 0.0586 & 0.0005 \\
\hline dbeduc & Change in the fraction of adults with college degrees (Black population) & 0.0101 & 0.0007 & 0.0112 & 0.0008 \\
\hline manu90 & Fraction of the employed population in manufacturing in 1990 (Black population) & 0.3310 & 0.0026 & 0.3056 & 0.0006 \\
\hline serv90 & Fraction of the employed population in services in 1990 (Black population) & 0.5918 & 0.0030 & 0.6213 & 0.0008 \\
\hline HBCU & Distance to the nearest Historically Black College or University in miles & 37.2891 & 0.5381 & 312.9890 & 2.4596 \\
\hline PUBLIC & Distance to the nearest public college or university in miles & 16.9490 & 0.2847 & 15.9921 & 0.1258 \\
\hline ALL & Distance to the nearest public college or university in miles & 15.8063 & 0.2651 & 15.8640 & 0.1252 \\
\hline Sample size & & 1,114 & & 24,281 & \\
\hline
\end{tabular}

Note: The means and standard deviations have been weighted by the subdivision population. 
In this paper we use the geographic information system ARC-VIEW along with data on college and university zip codes and county subdivision center coordinates to generate measures of straight-line distance from the center of each county subdivision to the nearest accredited HBCU granting a bachelors degree. While not an all-encompassing measure of access to postsecondary education, the straight-line distance measure is expected to be strongly correlated with the social and physical costs associated with HBCU attendance.

\subsection{Marginal influence of HBCUs}

HBCUs are not the only, and often not the closest, college or university accessible to rural Blacks. In order to understand the unique impact that HBCUs have had on college attendance, we controlled for access to the nearest college or university regardless of HBCU status, and access to the nearest public university. The impact of HBCUs under this specification is thus two-fold. First it has the general impact that is associated with any college or university (or any public college or university if it is publicly funded). Secondly it has a unique impact associated with their special status, reflected in the HBCU parameter estimate.

\subsection{Endogenous Location}

A potential econometric concern in this model is that the location of HBCUs may not be independent of educational attainment and income. An upwardly biased estimate of the influence of HBCU access on educational attainment would arise if HBCUs were established in counties with prior high levels of college education or relatively high incomes. However, establishing HBCUs in counties that were already relatively prosperous would have violated the mandate of increasing accessibility among the most disadvantaged. Moreover, per capita incomes in rural counties with an HBCU were in fact lower on average in 2000 than for all racially diverse rural counties, for both Blacks $(\$ 8,728)$ and the general population $(\$ 14,239)$.

Several tests are run to assess the robustness of the estimated association between HBCU access and educational attainment. First, a measure of county subdivision real per capita income is included in the initial regression equation. Per capita income and the share of adults with a four-year college degree are clearly jointly determined variables; thus the inclusion of per capita income in 2000 in the regression equation may present an endogeneity problem. To correct for potential endogeneity, we use 1990 county subdivision per capita income to proxy 2000 income. ${ }^{2}$ A significant parameter estimate for distance from the county subdivision to the nearest HBCU even after controlling for real income differences suggests either a real association between access and attainment or the possibility of spurious correlation from a third factor.

\footnotetext{
${ }^{2}$ Income in 1990 has a partial effect on the share of college graduates in 2000, but the latter cannot cause income levels in 1990.
} 
To address this additional concern, two alternative regression models are estimated. Under the first alternative specification, we estimate the impact of HBCU access on overall adult educational attainment - regardless of race - in racially diverse rural counties. If the coefficient estimate for HBCU access in this specification is similar to that in the initial specification for Blacks, one might conclude that the observed relationship between access and Blacks' educational attainment does not stem from improved access for rural Blacks. Under the second alternative, the change in the share of county subdivision Black adults with college degrees between 1990 and 2000 is regressed on the same set of independent variables.

\subsection{Heteroskedasticity}

Using an aggregated county subdivision data set imbeds heteroskedasticity into the statistical model if the model with individual level data satisfies the homoskedasticity assumption (Wooldridge 2000). Specifically, the error in the statistical model is proportional to the inverse of the population size. Weighted least squares estimation, using the respective population size as the weighting variable, is therefore appropriate. This procedure assumes that the underlying individual-level equation satisfies the standard GaussMarkov assumptions, although this is untestable. Further, concerns about heteroskedasticity in the model arise due to the complex sampling framework of the underlying Census data. Therefore, heteroskedasticity-robust standard errors are also estimated.

The basic empirical model to be estimated is then:

$$
\omega_{i} y_{i}=\omega_{i} X_{i} B+\varepsilon_{i}
$$

where

$\omega_{i}$ is a weight equal to the population size for each data point; $y_{i}$ is a measure of the share of Blacks 25 years of age or older with a college degree in subdivision $i$ of a racially diverse county; $X_{i}$ is a vector of the independent variables distance to the nearest college or university (ALL), distance to nearest public college or university (Public), distance to the nearest HBCU, and real per capita income in 1990 (INC); and $\varepsilon_{i}$ is the error term.

\subsection{Results}

Regression results for the share of Black adults with a four-year college degree in racially diverse counties (Model 1) and all adults with a college degree in these counties (Model 2) are presented in Table 2. In Model 1, distance to the nearest college or university regardless of status is negatively related to the share of college-educated Blacks. Distance to the nearest HBCU is also negatively related to Black educational attainment. Thus, as access to HBCUs decays with distance, the share of Blacks with college degrees declines even after controlling for the presence of other colleges or universities and per capita income. In fact, the parameter estimate suggests that a 10 mile decrease in 
distance from the nearest Historically Black College or University leads to a 0.8 percentage point increase in the incidence of college degrees among adult Blacks.

As expected, per capita income in the county subdivision also shows a significant relationship with the incidence of college degrees among Black adults. As previously noted, the fact that the parameter estimate of distance to the nearest HBCU is significant even after holding per capita income constant suggests that the association between distance to HBCUs and educational attainment does not stem from HBCUs having been located in areas of relative prosperity.

Model 2 regresses the share of all adults in racially diverse rural counties with college degrees on the same set of independent variables used in Model 1. The parameter estimate on distance to the nearest HBCU, while still significant in Model 2, is much smaller in magnitude ( 0.35 versus a 0.80 percentage point increase in share per 10 mile decrease in distance to the nearest HBCU). Thus, the association between educational attainment and HBCU access occurs mainly within the adult Black population. The share of all adults with a college degree also rises with decreasing distance from the nearest college or university regardless of status.

Models 3 and 4 regress the change between 1990 and 2000 in the share of Blacks and all adults, respectively, who have college degrees in racially diverse rural counties on the same set of independent variables as Models 1 and 2. However the fraction of the Black adult population with college degrees in 1990 is also included in Model 3 in order to control for initial levels. A similar variable is added for the general population in Model 4. The results show that distance from the nearest college or university and distance to the nearest public college or university show no significant effect upon the change in the share of Black adults with a college degree, nor does per capita income in 1990 (Table 2). However, distance to the nearest HBCU does show a significant $(p=0.01)$ effect on the change in share, 0.29 percentage points for every 10 miles closer a county subdivision is to the nearest HBCU. The share of Black adults with a college degree in 1990 also shows a significant $(\mathrm{p}=0.01)$ negative correlation with the growth in the share of college-educated Black adults, suggesting that the greatest gains in attainment occurred in county subdivisions with lower initial shares of college-educated Blacks.

For the general population in Model 4, distance to the nearest public college shows a significant $(\mathrm{p}=0.05)$ impact on change in the share of all adults with college degrees, but the distance to the nearest HBCU has no impact. Further, an F-test indicates that the regression as a whole is not significant. Thus Model 4 is consistent with the notion that access to HBCUs has an unique impact upon Black attainment.

\section{EDUCATION AND INCOME GROWTH}

The effects that college education of Blacks and of all adults in racially diverse rural counties have on the economic well being of county subdivisions are explored in this section. Specifically, we estimate a linear regression model that examines the impact of 
TABLE 2

Impact of College Locations on Postsecondary Education Attainment in Racially Diverse Rural Counties (RDRCs)

\begin{tabular}{|c|c|c|c|c|c|c|c|c|c|}
\hline \multirow[b]{3}{*}{ Variable } & & \multicolumn{4}{|c|}{$\begin{array}{l}\text { Share of Adult Population with College } \\
\text { Degrees in Subdivisions of RDRCs }\end{array}$} & \multicolumn{4}{|c|}{$\begin{array}{l}\text { Change in Share of Adult Population with } \\
\text { College Degrees in Subdivisions of RDRCs }\end{array}$} \\
\hline & & \multicolumn{2}{|c|}{$\begin{array}{l}\text { Black Population } \\
\text { (Model 1) }\end{array}$} & \multicolumn{2}{|c|}{$\begin{array}{c}\text { Whole Population } \\
\text { (Model 2) }\end{array}$} & \multicolumn{2}{|c|}{$\begin{array}{l}\text { Black Population } \\
\text { (Model 3) }\end{array}$} & \multicolumn{2}{|c|}{$\begin{array}{c}\text { Whole Population } \\
\text { (Model 4) }\end{array}$} \\
\hline & & Coefficient & S. E. & Coefficient & S. E. & Coefficient & S. E. & Coefficient & S. E. \\
\hline Intercept & Distance to the nearest & 0.0920 & 0.0090 & 0.0990 & 0.1200 & 0.0340 & 0.0010 & 0.0019 & 0.0030 \\
\hline HBCU (10 mi) & $\begin{array}{l}\text { HBCU measured in } 10 \mathrm{mi} \\
\text { intervals } \\
\text { Distance to the nearest } \\
\text { college measured in } 10 \mathrm{mi}\end{array}$ & -0.0080 & 0.0018 & -0.0035 & 0.0017 & -0.0029 & 0.0007 & -0.0001 & 0.0060 \\
\hline ALL (10 mi) & $\begin{array}{l}\text { intervals } \\
\text { Distance to the nearest } \\
\text { public college measured in }\end{array}$ & -0.0146 & 0.0082 & -0.0124 & 0.0059 & -0.0023 & 0.0029 & -0.0026 & 0.0250 \\
\hline PUBLIC (10mi) & $\begin{array}{l}10 \text { mi intervals } \\
\text { Real per capita income }\end{array}$ & -0.0038 & 0.0080 & -0.0046 & 0.0057 & -0.0017 & 0.0028 & -0.0450 & 0.0230 \\
\hline INC (10000USD) & $\begin{array}{l}(1990) \\
\text { Adults with college degrees }\end{array}$ & 0.0400 & 0.0180 & 0.0752 & 0.0128 & 0.3610 & 0.7405 & 0.4480 & 0.3340 \\
\hline EDUC90 & (percent 1990) & & & & & -0.2400 & 0.0570 & 0.0270 & 0.0260 \\
\hline Adj R-Sq & & 0.2000 & & 0.2060 & & 0.1160 & & 0.0100 & \\
\hline F Value & & 7.2200 & & 21.660 & & 10.4500 & & 1.7800 & \\
\hline Sample & & 1,114 & & 1,114 & & 1,114 & & 1,114 & \\
\hline
\end{tabular}


college education on the per capita income growth of Blacks and the general population in racially diverse rural counties as well as across all rural U.S. county subdivisions for comparison.

The model captures the impact of college education in two ways. First, consistent with the notion of education as a stock asset (Romer 1990; Nelson and Phelps 1966), the initial fraction of the adult population ages 25 and older with a college degree is included as an independent variable. Second, consistent with Lucas (1988), the effect of the accumulation of human capital on income growth is accounted for by including the change in the share of adults with a college degree. Several potential data and specification problems arise in this model, including: (1) disentangling causality between education and income growth in linear regression models, (2) overcoming the lack of subdivision-level data on physical capital, and (3) accounting for potential heteroskedasticity in the statistical model.

\subsection{Causality of Education and Income Growth}

The inclusion of initial levels of education obviously presents no cause for concern about endogeneity. The growth in the share of college-educated adults, however, may be endogenous in an income growth model, as change in educational composition and income are likely jointly determined. Faster growing areas may experience an increase in the demand for skilled labor and increasing returns to college education, thereby inducing private investments in college education and/or attracting college educated young adults to the area. Bils and Klenow (2000) find that more than half of the correlation between schooling and income growth across countries can be explained by the effects of higher growth on schooling.

Several recent studies use natural experiments to obtain valid instrumental variables in order to correct for endogeneity bias. ${ }^{3}$ An instrumental variable needs to satisfy two assumptions. First, it needs to be correlated with the endogenous independent variable. Second, it needs to be orthogonal to the error term in the income growth equation (Wooldridge 2000). In Section 3 we argued that the location of an HBCU is uncorrelated with subdivision per capita income other than through its impact on educational attainment. Also, Model 3 (Table 2) shows that distance to the nearest HBCU is significantly correlated with the change in the share of college graduates among the adult Black population in racially diverse rural counties. Thus distance to the nearest HBCU is used as an instrumental variable for change in educational attainment to correct for endogeneity bias in the model for Blacks. Results are then reported for both the instrumented and noninstrumented models. For the regression equations on the general population in racially diverse rural counties, and those estimated for all subdivisions in the rural U.S., no such instrument is available. Thus a direct measure of the change in the share of college

\footnotetext{
${ }^{3}$ For a review on natural and policy experiments being used as instrumental variables see Card (2001).
} 
graduates is used in these models, acknowledging that the parameter estimates may potentially display positive endogeneity bias.

\subsection{Physical Capital}

The endowment of physical capital in the base period and its rate of accumulation also impact per capita income growth. It is thus desirable to include measures of physical capital in income growth regressions. County subdivision level data on physical capital are not available. Several studies use economic base variables such as the share of employment in manufacturing and transfer payments as proxies for physical capital (Krueger and Lindahl 2001). For example, Simon and Nardinelli (2002) use the fraction of employment in manufacturing to control for variability in aggregate production functions across counties. We use the fraction of employment in manufacturing and construction and in services and public administration in 1990 to proxy the variability in physical capital across county subdivisions, leaving the fraction of employment in agriculture fisheries and forestry in 1990 as the base group. This implicitly assumes that the capital-labor ratio is relatively constant across county subdivisions within these broad groupings.

\subsection{Heteroskedasticity}

The same concerns about heteroskedasticity pertain in this model as in the previous statistical models. Therefore the income growth equations are also estimated using WLS, where subdivision population size is the weighting variable. Robust standard errors are also reported.

The model is specified as:

$$
W_{i} I_{i}=W_{i} C_{i} \gamma+e_{i}
$$

where $W_{i}$ is a vector of weights equal to the appropriate population size; $I_{i}$ is the growth rate in per capita income for the census period $[I=(\mathrm{Ln}$ Income00 - Ln Income 90)] in county subdivision $i$; and $C$ is a matrix of the independent variables including: the share of adults ages 25 and older with at least a four year college degree in 1990 (EDUC), the change in this share between 1990 and 2000 (DEDUC), the share of employment in manufacturing and construction in 1990 (MANU), the share of employment in services or the public sector in 1990 (SERV).

For the regressions performed on all rural county subdivisions, the Black share of the population is also included ${ }^{4}$ and $e_{i}$ is the error term. As noted, (DEDUC) is instrumented in model 6.

\footnotetext{
${ }^{4}$ The share of Blacks in the population has not been included in the regressions estimated for the racially diverse rural counties because this variable is truncated at one third or more Blacks by definition.
} 


\subsection{Results}

Income growth regression results are shown in Table 3. Model 5 regresses per capita income growth for Blacks in racially diverse rural county subdivisions on the share of Black adults with at least a four-year degree in 1990, the growth rate in this share, the fraction of the workforce employed in manufacturing and construction in 1990, the fraction of the workforce employed in the service sector and public administration in 1990, and the log of real per capita income for Blacks in 1990. Model 6 uses the same set of dependent and independent variables, but with the educational attainment change for Blacks instrumented.

Results for Models 5 and 6 indicate that the growth of the share of college-educated Black adults in racially diverse rural counties is positively correlated $(p=0.01)$ with the rate of real per capita income growth of Blacks. Parameter estimates in Model 5 indicate that a one percentage point increase in the growth between 1990 and 2000 in the share of college-educated Black adults yields an additional 1.4 percentage point increase in per capita income (2.4 percentage point increase in the IV Model 6). The parameter estimate in the IV model, while expected to be lower than in the non-instrumented model, is in fact higher. One weakness of the specification is that the use of aggregate data does not allow us to control for the quality and type of education institution that college-educated adults have attended. The unexpected increase in the change in education parameter when instrumented may stem from the previous finding of Constantine (1995) that Blacks who attend HBCUs realize higher returns to college education than Blacks from other colleges and universities. The parameter estimates for the instrumented and noninstrumented models are, however, not statistically different from each other at the $\mathrm{p}=0.05$ confidence level. It is thus safe to conclude that the results provide no evidence of positive endogeneity bias in the Model.

The results also indicate that the initial share of college-educated Black adults has no significant impact upon subsequent income growth. But per capita income in the initial period is negatively correlated with the income growth rate for Blacks in racially diverse rural counties, suggesting that Blacks in these counties with lower initial per capita incomes have realized greater rates of per capita income growth during the 1990s.

Model 7 uses the same set of variables applied to the general population in racially diverse rural counties. The results indicate that both the initial endowment of collegeeducated adults and the change in the share of educated adults are positively correlated with per capita income growth. Parameter estimates suggest that a one percentage point higher share of college-educated adults in 1990 is associated with a 1.5 percentage point increase in real per capita income growth rate over the subsequent decade, and a one percentage point higher rate of change in attainment between 1990 and 2000 is associated with a 2.6 percentage point increase in the rate of income growth for the general population in racially diverse rural counties over the same time period. Initial per capita income also continues to show a significant negative relationship with income growth, again 
TABLE 3

Impact of College Education on Income Growth

\begin{tabular}{|c|c|c|c|c|c|c|c|c|c|c|c|}
\hline \multirow[b]{3}{*}{ Variable } & & \multicolumn{6}{|c|}{$\begin{array}{c}\text { Growth Rate in Per Capita Income in Subdivisions of RDRCs } \\
\text { Between } 1990 \text { and } 2000\end{array}$} & \multicolumn{4}{|c|}{$\begin{array}{l}\text { Growth Rate in Per Capita Income in } \\
\text { Subdivisions of Rural Counties } \\
\text { Between } 1990 \text { and } 2000\end{array}$} \\
\hline & & \multicolumn{2}{|c|}{$\begin{array}{l}\text { Black Population } \\
\text { (Model 5) }\end{array}$} & \multicolumn{2}{|c|}{$\begin{array}{l}\text { Black Population } \\
\text { (Model 6) }\end{array}$} & \multicolumn{2}{|c|}{$\begin{array}{l}\text { Whole Population } \\
\text { (Model 7) }\end{array}$} & \multicolumn{2}{|c|}{$\begin{array}{l}\text { Black Population } \\
\text { (Model 8) }\end{array}$} & \multicolumn{2}{|c|}{$\begin{array}{l}\text { Whole Population } \\
\text { (Model 9) }\end{array}$} \\
\hline & & Coefficient & S. E. & Coefficient & S. E. & Coefficient & S. E. & Coefficient & S. E. & Coefficient & S. E. \\
\hline Intercept & & 5.3910 & 0.2921 & 5.4360 & 0.2949 & 8.2840 & 0.4091 & 5.8401 & 0.1922 & 8.7392 & 0.4703 \\
\hline LnINC90 & $\begin{array}{l}\text { Log of real per capita } \\
\text { income (1990) } \\
\text { Adults with degrees }\end{array}$ & -0.6253 & 0.0410 & -0.6322 & 0.0361 & -0.9330 & 0.0550 & -0.6651 & 0.0221 & -0.9460 & 0.0512 \\
\hline EDUC & $\begin{array}{l}\text { (Percent 1990) } \\
\text { Change in percent of adults }\end{array}$ & 0.2081 & 0.2671 & 0.4182 & 0.3940 & 1.5211 & 0.2426 & 0.4748 & 0.0961 & 1.1827 & 0.0932 \\
\hline DEDUC & & 1.4411 & 0.2680 & 2.3030 & 0.1890 & 2.6371 & 0.2942 & 1.0861 & 0.0910 & 1.8600 & 0.0821 \\
\hline MANU & $\begin{array}{l}\text { manufacturing (1990) } \\
\text { Share of employment in }\end{array}$ & 0.5330 & 0.1320 & 0.5320 & 0.1333 & 0.7558 & 0.1211 & 0.5390 & 0.1037 & 0.6201 & 0.0204 \\
\hline SERV & $\begin{array}{l}\text { services (1990) } \\
\text { Blacks as a percent of }\end{array}$ & 0.3921 & 0.1450 & 0.3441 & 0.2951 & 0.2972 & 0.1341 & 0.3872 & 0.1059 & 0.2054 & 0.0285 \\
\hline PBlck & population (1990) & & & & & & & -0.1560 & 0.0211 & -0.4165 & 0.0080 \\
\hline Adj R-Sq & & 0.4020 & & 0.3910 & & 0.8850 & & 0.3910 & & 0.9170 & \\
\hline F Value & & 72.8600 & & 64.5700 & & 87.460 & & 225. 9700 & & 7050.1400 & \\
\hline Sample & & 1,114 & & 1,114 & & 1,114 & & 24,281 & & 24,281 & \\
\hline
\end{tabular}


suggesting that areas with low initial per capita income have seen larger income growth rates among the general population.

Models 8 and 9 apply the same specification as in Models 5 and 7 to the Black and general population, respectively, of all rural U.S. counties. The level of college educational attainment in 1990 and the subsequent change in share are significantly correlated with income growth for both Blacks and the general population across the rural U.S. Parameter estimates suggest that a one percentage point higher share of Black collegeeducated adults in 1990 yields a 0.5 percentage point gain in income growth for Blacks. Similarly the gain for the general population in the rural U.S. is 1.2 percentage points. A one percentage point increase between 1990 and 2000 in the share of Black collegeeducated adults yields a 1.1 percentage point gain in the income growth rate for all rural Blacks, while a similar change among the general population in the rural U.S. leads to 1.9 percentage point increase in income growth.

\subsection{Comparing Returns to Education}

Comparing parameter estimates indicates that both the initial endowment and the change in the share of college-educated adults produce smaller gains in the real per capita income growth rate between 1990 and 2000 for Blacks in subdivisions of racially diverse rural counties than for the general population in these counties (Table 3). Blacks across the rural U.S. also show lower parameter estimates for the impact of initial education base and change in educational attainment on income growth than does the general rural population (Table 3). Further, Blacks in racially diverse rural counties show lower income response to the initial endowment of college-educated adults than do Blacks across the rural U.S. However, they have comparable returns to changes in the share of college-educated adults by one estimate (Model 5), and the returns to the change in the share of adults with a college degree for Blacks in racially diverse rural counties is larger than that for all rural Blacks when change in education is instrumented (Model 6).

\section{CONCLUSIONS}

Blacks in racially diverse rural counties show relatively low levels of postsecondary educational attainment and income compared with the general population. This study finds that Blacks in racially diverse rural counties experienced lower income growth for a given level of education compared with other Blacks or the general population during the 1990s. Aggregate returns on new investment in postsecondary education were, however, at least as high or higher for Blacks in racially diverse rural counties as for other groups. These findings suggest that Blacks in racially diverse rural counties continue to have difficulties converting human capital into income growth, but that Blacks may have seen modest convergence in returns to education during the decade. The slight improvement is likely concentrated among more recent college graduates.

Given the finding that growth in the share of college-educated Black adults in racially diverse rural counties significantly increases the income growth rate, enhancing college 
education among Blacks may be an important goal for policy initiatives aiming to stimulate development in these counties. As previously discussed, the decision of individuals to pursue a college education depends on both the costs of, and expected returns to, education. This study suggests that proximity to HBCUs significantly reduces these costs for Blacks, and that their impact exceeds that of other colleges and universities. Thus, HBCUs appear to remain an effective policy instrument for rural development.

Several additional research questions arise from this study. Most importantly, does the rate of return to a degree from an HBCU differ from the rate provided by other institutions for Blacks in racially diverse rural counties? If so, HBCUs are even stronger drivers of economic development than is estimated in the current study. An individuallevel dataset is needed in order to further explore this question. Another concern that needs further exploration arises from the finding that the fraction of the county subdivision population that is Black is significantly and negatively correlated with income growth. This suggests that even after controlling for the initial fraction of adults with a college degree, change in the share of adults with college degrees, and physical capital, both the general population and Blacks see lower rates of income growth in subdivisions with higher fractions of Blacks. Thus, there appears to be a persistent constraint on income growth associated with the concentration of Blacks in rural areas. Identifying and addressing this constraint may also be important in furthering economic growth and equality in rural America.

\section{REFERENCES}

Akerlof, G.A. and R.E. Kranton, 2002. "Identity and Schooling: Some Lessons for the Economics of Education,” Journal of Economic Literature 40(4), 1167-1201.

Bils, M. and P.J. Klenow, 2000. "Does Schooling Cause Growth?” American Economic Review, 90(5), 1160-184.

Brazziel. W.F., 1983. "Baccalaureate College of Origin of Black Doctorate Recipients," The Journal of Negro Education 52(2), 102-09.

Card, D., 1995. "Using Geographic Variation in College Proximity to Estimate the Return to Schooling,” in L.N. Christofides, E.K. Grant, and R. Swidinsky (eds.), Aspects of Labor Market Behavior: Essays in Honor of John Vanderkamp. University of Toronto Press: Toronto, 201-22.

, 2001. "Estimating the Return to Schooling: Progress on Some Persistent Econometric Problems,” Econometrica 69(5), 1127 -1160.

Constantine. J.M., 1995. "The Effect of Attending HBCUs on Future Wages of Black Students," Industrial and Labor Relations Review 48, 531-46.

Cook, P. (ed.), 1999. Rural Conditions and Trends 9. U.S. Department of Agriculture, Economic Research Service: Washington D.C.

Darity, W. and P.L. Mason, 1998. "Evidence on Discrimination in Employment: Codes of Color, Codes of Gender," The Journal of Economic Perspectives 12(2), 63-90.

Krueger, A.B. and M. Lindahl, 2001. "Education for Growth: Why and for Whom?" Journal of Economic Literature 39(4), 1101-1136. 
Lucas, R., 1988. “On the Mechanics of Economic Development,” Journal of Monetary Economics 22, 3-42.

Mykerezi, E., B.F. Mills, and S. Gomes, 2003. "Education and Socioeconomic WellBeing in Racially Diverse Rural Counties," Journal of Agricultural and Applied Economics 35(2), 251-62.

Nelson R. and E. Phelp, 1966. "Investment in Humans, Technological Diffusion, and Economic Growth,” American Economic Review 61, 69-75.

Romer, P., 1990. “Endogenous Technological Change,” Journal of Political Economy 98(5), S71-102.

Simon, C.J. and C. Nardinelli, 2002. "Human Capital and the Rise of American Cities," Regional Science and Urban Economics 32, 59-96.

U.S. Department of Education, 1997. Digest of Education Statistics 1997. National Center for Education Statistics: Washington D.C.

Wooldridge, J.M., 2000. Introductory Econometrics: A Modern Approach. SouthWestern College Publishing: Mason, $\mathrm{OH}$. 